UDK 528.92

\title{
POŽEMINIŲ KOMUNIKACIJŲ GEOINFORMACINIŲ DUOMENŲ KAUPIMO TRIMAČIAME GEOINFORMACINÉS SISTEMOS MODELYJE YPATUMŲ TYRIMAS
}

\author{
Kęstutis Čypas \\ Geodezijos ir kadastro katedra, Vilniaus Gedimino technikos universitetas, \\ Sauletekio al. 11, LT-10223 Vilnius-40, Lietuva, \\ el.paštas: kestutis.cypas@ap.vtu.lt
}

Iteikta 20050701, priimta 20050707

\begin{abstract}
Santrauka. Straipsnyje apibendrinami požeminių komunikacijų, kaip antai: vandentiekio, dujotiekio, naftotiekio, elektros tinklų, - geoinformacinių duomenų kaupimo ir saugojimo trimačiame geoinformacinès sistemos modelyje savivaldybės poreikiams ypatumai. Atlikta miesto geoinformacinejje sistemoje kaupiamų požeminių komunikaciju geoinformacinių duomenų analizè ir apibrèžti požeminių komunikacijų geoinformacinių duomenų kaupimo trimačiame geoinformacinés sistemos modelyje reikalavimai atliekant geodezines nuotraukas. Straipsnyje pateikiamos ir sprendžiamos šios problemos: 1) kol kas geoinformacinių duomenų kaupimo procedūros užtikrina geoinformaciniu duomenų saugojimą tik 2,5 dimensijoje, todèl apibrèžti papildomi požeminių komunikacijų geoinformacinių duomenų kaupimo trimačiame geoinformacinès sistemos modelyje reikalavimai, 2) miesto geoinformacinėje sistemoje duomenys saugomi 2,5D erdveje, todèl geoinformaciniai duomenys transformuoti i $3 \mathrm{D}$ erdvę taikant tinklų klojimo altitudžiu reikšmes, o esant nepakankamam klojimo altitudžių kiekiui, atliktas linijų viršūnių altitudžių interpoliavimas. Sukurtas ir pateiktas požeminių komunikacijų linijų viršūnių altitudžių nustatymo taikant tinklų klojimo altitudžių reikšmes veiksmų seku algoritmas; eksperimentui atlikti Visual Basic ${ }^{\mathrm{TM}}$ progamavimo kalba sukurtas programinis modulis, veikiantis $A r c G I S^{\mathrm{TM}}$ aplinkoje; taikant $U M L C A S E$ priemones sukurtas požeminių komunikacijų 3D geoduomenų modelis.
\end{abstract}

Raktažodžiai. 3D GIS požeminių komunikacijų geoinformacinių duomenų modelis, linijų viršūnių altitudžių nustatymas, altitudžių interpoliavimas.

\section{Ivadas}

Projektuojant ir statant ivairius statinus ir pastatus miesto teritorijose reikalingi tikslūs požeminių komunikacijų padèties ir aukščių duomenys. Šie duomenys yra saugomi miesto geoinformacinèje sistemoje arba planšetèse. Projektuotojai projektuodami, o statybininkai tiesdami naujas komunikacijas neretai negauna tikslios informacijos apie esamų komunikaciju aukščius, o kartais ir planimetrinę padetį. Viena iš aukščiu netikslumo priežasčių - surenkama nepakankamai informacijos apie komunikacijų vertikaliają padèti. „Statomų požeminių tinklų ir komunikacijų geodeziniu nuotrauku atlikimo tvarkoje“" [1] nurodoma, kurių geoobjektų turi būti nustatoma ir vertikalioji padètis. Pagal egzistuojančią tvarką kabelinių komunikacijuc altitudès be papildomuc reikalavimu apskritai nenustatomos, todèl geodezininkai, atlikdami geodezines nuotraukas, nerenka nereikalaujamos informacijos. Kabelinių komunikacijų planimetrinè padètis taip pat ne visada tiksliai žinoma, nors reikalaujama nustatyti posūkių, jungčių padèti, o esant tiesiems tarpams padètis turi būti nustatoma ne rečiau kaip kas 50 metrų. Kabelinès linijos dažnai vingiuoja, ir nustatyti tikslią posūkio vietą sudetinga. Naudojant šiuolaikinius elektroninius tacheometrus padetị ir aukščius nustatyti bei įvesti nèra sudètinga, todèl galima pateikti papildomus duomenų surinkimo sudarant požeminių komunikacijų geodezines nuotraukas reikalavimus.

Miesto geoinformacineje sistemoje kaupiami požeminių komunikacijų geoinformaciniai duomenys saugomi 2,5D erdveje, t. y. vamzdinių ir laidinių komunikacijų duomenys saugomi kaip linijiniai geometriniai elementai, o klojimo altitudžių duomenys atskirame taškiniame sluoksnyje. Taikant trimati geoduomenų modelị kiekviena linijinès požeminès komunikacijos viršūnè būtų saugoma trimatèje erdvejje, t. y. su aukščio reikšme tame taške. Tam tikslui reikia kartografuoti kiekvienos viršūnès ne tik planimetrinę, bet ir aukščių padètį. Sudarius trimati modeli galima būtų saugoti bei panaudoti trimačius geoinformacinius duomenis, o papildžius duomenų surinkimo reikalavimus - tokius duomenis sukaupti.

Ir geodezininkai, ir architektai naudoja šiuolaikines geodeziniu nuotrauku sudarymo bei projektavimo programas, kurios leidžia ivvesti bei saugoti duomenis trimateje erdvèje. Architektai, projektuodami naujus statinius bei požemines komunikacijas, galètų pasinaudoti trimačiais geoinformaciniais duomenimis ir tiksliau projektuoti, o statybininkai - tiksliau realizuoti tai statybu aikštelèje.

Straipsnyje pateikiamos ir sprendžiamos šios problemos: 1) geoinformacinių duomenų kaupimo procedūros užtikrina geoinformacinių duomenų saugojimą tik 2,5 dimensijoje, todèl apibrèžti papildomi 
reikalavimai požeminių komunikacijų geoinformaciniams duomenims kaupti trimačiame geoinformacinès sistemos modelyje, 2) miesto geoinformacinèje sistemoje duomenys saugomi 2,5D erdvèje, todèl taikant klojimo altitudžių reikšmes transformuoti i 3D erdvę, o esant nepakankamam klojimo altitudžių kiekiui, atliktas liniju viršūnių altitudžių interpoliavimas. Sukurtas ir pateiktas požeminių komunikacijų linijų viršūnių altitudžių nustatymo taikant klojimo altitudžių reikšmes veiksmų seku algoritmas; eksperimentui atlikti Visual Basic ${ }^{\mathrm{TM}}$ programavimo kalba sukurtas programinis modulis, veikiantis $A r c G I S^{\mathrm{TM}} 9.0$ aplinkoje; taikant $U M L C A S E$ priemones sukurtas požeminių komunikacijų 3D geoinformacinis duomenų modelis.

\section{Požeminių komunikacijų geoinformacinių duomenų kaupimo trimačiame geoinformacinès sistemos modelyje reikalavimai}

Reikalavimai, keliami statomų požeminių komunikaciju geodezinėms nuotraukoms atlikti, pateikti Techninių reikalavimų reglamente „Statomų požeminių tinklų ir komunikacijų geodezinių nuotraukų atlikimo tvarka“ [1]. Pagal reglamentą nustatomos tik šių požeminių komunikacijų objektų altitudès:

- visų irenginių viršaus (dangčio žiedo);

- $\quad$ i šulinius ieinančiuz arba iš jų išeinančių vamzdžių (savitakinių komunikacijų - nuotekų ir drenažo vamzdžio latako), kitų vamzdžių - vamzdžio viršaus;

- telefono kabelių - vamzdžio latako, jei vamzdžių pluoštas - apačios ir viršaus;

- vienodo nuolydžio atkarpu - ne rečiau kaip kas 50 m. Altitudès nustatomos $1 \mathrm{~cm}$ tikslumu. Taip pat nurodoma, kad kabelinių komunikaciju altitudès papildomai nereikalaujant nenustatomos. Techninių reikalavimų reglamente „Statybiniai inžineriniai geodeziniai tyrinejjimai“ [2] nurodoma, kad atliekant požeminių komunikacijų tyrinejjimus sudaroma inžinerinių statinių nuotrauka, kurioje turi būti nustatomi šulinio angos dangčio, žemès paviršiaus prie šulinio aukščiai, šulinyje esančiuc vamzdžių, kabelių, kanalų aukščiai, o matavimai nuo šulinio angos žiedo turi būti atliekami $1 \mathrm{~cm}$ tikslumu (sudaroma šulinio inventorizacijos kortelè). Nematomu tašku planimetrinė padètis bei jų aukštis gali būti nustatomas ieškikliais, o matavimų rezultatų skirtumas matuojant du kartus neturi skirtis daugiau kaip $15 \%$.

Minetuosius reikalavimus rekomenduojama papildyti. Matuojant altitudès turi būti nustatomos:

- $\quad$ i kabelinių požeminių komunikacijų šulini ar kamerą ieinančių ir išeinančių kabelių;

- $\quad$ kabelinių požeminių komunikacijų posūkių, jungčių (movu), ivadų taškuose;

- kabelinių požeminių komunikacijų ryškaus nuolydžio kitimo taškuose;

- kabelinių požeminių komunikacijų tiesių tarpu taškuose - ne rečiau kaip kas $50 \mathrm{~m}$.

Iš esmès siūloma nustatyti kabelinių komunikacijų charakteringujuc vietų altitudes, planimetrinę padèti, susieti planimetrines koordinates su altitude.
Laikantis minètosios tvarkos suformuluoti šie požeminių komunikacijų geoinformacinių duomenu kaupimo trimačiame geoinformacinès sistemos modelyje reikalavimai:

1. Linijinių požeminių komunikacijų geoobjektu ivedimas:

- linijos geometrija ivvedama kartu ivvedant ir linijos viršūniu altitudes (taikant polylineZ geoinformacinių duomenu tipa) arba fiksuojant altitudžių reikšmes atskirame taškiniame sluoksnyje. Vèliau taikant požeminių komunikaciju liniju altitudžių nustatymo algoritmą būtų nustatomos visų linijos viršūnių altitudès;

- $\quad$ i linijų atributinès duomenų bazès laukus turi būti ivedamos techninès charakteristikos, nurodytos techniniu reikalavimų reglamente [1]: priklausomai nuo paskirties komunikacija turi būti vedama i atitinkamą sluoksnį suteikiant $G$ kodo reikšmę; jei tai vamzdynai, turi būti nurodomi vamzdynų vidiniai skersmenys ir medžiaga, iš kurios pagaminti, jei komunikacijos savitakinès - nurodoma skysčio tekèjimo kryptis (siūloma îvesti azimuto reikšmę), o nuolydis (promilèmis) gali būti apskaičiuojamas automatiškai arba, jei apskaičiuotas kitais būdais, ivedamas; dujotiekiu papildomai nurodomas slègis, o kabelinių elektros komunikacijų - itampa; jei yra apsauginiai komunikacijų vamzdžiai, - taip pat nurodoma medžiaga, iš kurios jie pagaminti, ir skersmenys.

2. Taškinių požeminių komunikacijų geoobjektų ¿̨vedimas:

- taškinių objektų, tokių kaip: šulinių dangčiai, sklendès, - geometrija (ne tik planimetrinè padètis, bet ir altitudès) i̇vedama $\mathfrak{i}$ taškini sluoksni (taikant pointZ geoduomenu tipa). Jei komunikacijų klojimo altitudès išmatuotos atskirai, jos ivedamos i komunikacijų klojimo altitudžių taškinio sluoksnio, atitinkamą atributini lauką. Šios reikšmès vèliau bus nustatomos taikant požeminiu komunikacijų linijų altitudžių nustatymo algoritmą. Taškai turi jungtis su linijomis (snap režimas), kurios ị ši tašką ieina, t. y. turi būti užtikrinta tinklo topologija;

- taškinių objektų atributiniai duomenys ívedami i atitinkamus atributinius laukus. Priklausomai nuo tipo taškiniai objektai įvedami i atitinkamą taškini sluoksnį nurodant $G$ kodo reikšmę. Šulinių duomenys ìvedami iš šulinių inventorizacijos kortelès: miestas, gatvè, planšetès nomenklatūra, tipas, dangčio skersmuo ir medžiaga, iš kurios pagamintas, žemès altitudè, sienų ir dugno medžiaga, ieinančių ir išeinančių vamzdžių kiekis, kiekvieno ieinančio ir išeinančio vamzdžio tipas, skersmuo, lipynès tipas, laipteliu kiekis, nurodoma, ar yra vandens, dujų, taip pat nurodomas inventorizavęs asmuo bei inventorizavimo data. Atskaita (vamzdžio viršus ar apačia) ir atstumas nuo dangčio įvedamas i komunikacijų klojimo altitudžių sluoksnị. Klojimo altitude gali būti apskaičiuojama automatiškai pagal atstumą iki dangčio. Kitų taškinių objektų taip pat nurodoma vieta (miestas, gatvè), planšetès 
nomenklatūra, tipas. Turi būti galimybè saugoti nuskenuotą šulinio inventorizacijos kortelę.

3. Tūrinių požeminių komunikacijų geoobjektų ivedimas:

- tūriniai požeminiai objektai, tokie kaip: rezervuarai, kameros, - saugomi daugiasieniu sluoksnyje (taikant MultiPatch geoinforamciniu duomenu tipa). Tarpiniams duomenims ìvesti gali būti naudojami poligoninio tipo duomenys (PolygonZ), tuomet prie kiekvienos viršūnès įvedama tūrinio objekto apačios altitudès reikšmè;

- tūrinių objektų atributiniai duomenys ịvedami i atitinkamus atributinius laukus. Priklausomai nuo tipo tūriniai objektai įvedami ì atitinkamą sluoksni nurodant $G$ kodo reikšmę. Kaip atributinè reikšmė ivedamas objekto aukštis nuo apačios.

Turi būti suteikiama informacija apie visų objektų duomenų surinkimo metodą, tikslumą ir datą.

Geoinformaciniai duomenys turi būti saugomi centrinèje duomenų bazèje ir prieinami redaguoti ir peržiūrèti iš daugelio darbo vietų.

\section{Požeminių komunikacijų geoinformaciniai duomenys trimačiame geoinformacinès sistemos modelyje}

Miesto geoinformacinejje sistemoje kaupiamų ir saugomų požeminių inžinerinių komunikacijų objektai pateikti 1 lentelèje [3]. 2,5D geoinformacinès sistemos erdvèje saugomi inžinerinių komunikaciju geoinformaciniai duomenys su aukščių duomenimis kaip atributiniais atskirame taškiniame altitudžių duomenu sluoksnyje, t. y. altitudès nèra susietos su linijinių objektu geometrija tiesiogiai, todèl erdvè iš esmès ir toliau lieka dviejų dimensijų. Papildžius geoobjektus trečiaja dimensija, kiekvienas geometrinis objektas turès ir trečiają $-z$ koordinatę. Trečiosios dimensijos ịvedimas gali iš esmès keisti geometrini elementą, t. y. jei jis dvieju dimensijų erdvèje laikomas tašku, tai trijų dimensijų erdveje toks objektas gali tapti linijiniu, pvz., stulpas 2D erdvejje laikomas tašku, o 3D erdvejje tampa linija, ištęsta nuo žemès paviršiaus iki stulpo viršutinio taško. Galimas atvejis, kad taškas ir toliau lieka tašku, pvz., šulinio dangtis ir toliau tèra kaip taškas, skiriasi tik tai, jog šis taškas yra erdvèje, nes turi tam tikrą aukštį. Linijiniai objektai gali ir toliau likti linijiniais, tačiau kiekviena linijos viršūnè tampa susieta su altitude, linijos padètis apibūdinama ir vertikaliojoje aukščiu sistemoje. Plotai ir toliau gali likti plotiniais objektais arba gali būti transformuojami i tūrinius objektus. Tūriniai objektai tampa sudètiniais, t. y. sudètais iš plotinių (paviršiniu) dalių. Trimačiai objektai gali turèti arba vieną $z$ koordinatę (taškas, turintis aukšti, pvz., šulinio dangtis), arba jų aibę vertikaliojoje padètyje (stulpo apačios aukštis ir viršaus aukštis), arba jų aibę horizontaliojoje padètyje (vamzdinès ar laidinès komunikacijos, kurios kiekviena viršūnè turi $z$ koordinatę, 1 pav.)
1 lentelè. Požeminių komunikacijų objektai miesto geoinformacinèje sistemoje

Table 1. Main utility objects in city geoinformation system

\begin{tabular}{|l|l|}
\hline \multicolumn{1}{|c|}{$\begin{array}{c}\text { Komunikacijos } \\
\text { tipas }\end{array}$} & \multicolumn{1}{c|}{ Objektai } \\
\hline Elektros tinklai & $\begin{array}{l}\text { aukštosios itampos tiekimo linijos, } \\
\text { žemosios itampos paskirstymo kabeliai, } \\
\text { movos, transformatorinès }\end{array}$ \\
\hline $\begin{array}{l}\text { Vandentiekio } \\
\text { vamzdynai }\end{array}$ & $\begin{array}{l}\text { vandentiekio vamzdynai, kameros, } \\
\text { šulinių dangčiai, hidrantai, sklendės, } \\
\text { gręžiniai, rezervuarai }\end{array}$ \\
\hline $\begin{array}{l}\text { Dujotiekio } \\
\text { vamzdynai }\end{array}$ & $\begin{array}{l}\text { dujotiekio vamzdynai, šulinių dangčiai, } \\
\text { kameros, sklendès }\end{array}$ \\
\hline $\begin{array}{l}\text { Naftotiekio } \\
\text { vamzdynai }\end{array}$ & $\begin{array}{l}\text { naftotiekio vamzdynai, rezervuarai, } \\
\text { perpumpavimo stotys, rezervuarai }\end{array}$ \\
\hline $\begin{array}{l}\text { Šilumtiekio } \\
\text { komunikacijos }\end{array}$ & $\begin{array}{l}\text { šiluminès linijos, rezervuarai, kameros, } \\
\text { sklendès }\end{array}$ \\
\hline $\begin{array}{l}\text { Nuotekų } \\
\text { komunikacijos }\end{array}$ & $\begin{array}{l}\text { lietaus nuotekų vamzdynas, fekalinių } \\
\text { nuotekų vamzdynas, nuoteku šulinių } \\
\text { dangčiai, kameros, rezervuarai, pralaidos, } \\
\text { apsauginiai vamzdžiai }\end{array}$ \\
\hline $\begin{array}{l}\text { Ryšių } \\
\text { komunikacijos }\end{array}$ & $\begin{array}{l}\text { ryšių linijos, movos, ryšio požeminių } \\
\text { komunikacijų šulinių dangčiai, ryšio } \\
\text { kabelių paskirstymo spintos }\end{array}$ \\
\hline
\end{tabular}

Pereinant prie trijų dimensijų erdvès kartografuojami objektai transformuojami i 3D objektus, todèl reikia nustatyti, kokiu geometriniu elementu bus reprezentuojama kiekviena transformuotuju objektų grupè naujoje dimensijoje [4]. Bendri požeminių komunikacijų transformavimo iš $2 \mathrm{D}$ i $3 \mathrm{D}$ erdvę atvejai pateikti 2 lentelèje [5].

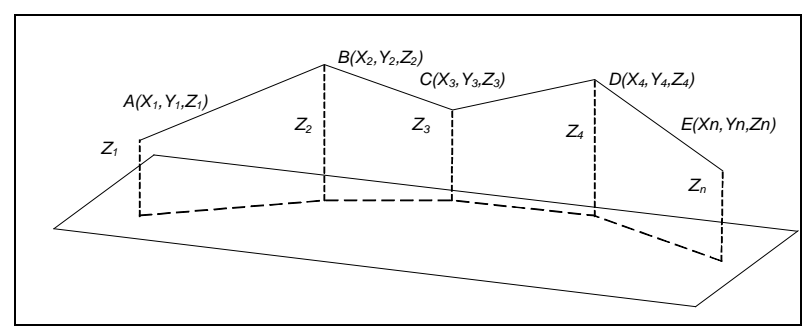

1 pav. Linija trijų dimensijų erdvejje

Fig 1. Line in three-dimensional space

\section{Inžinerinių komunikacijų geoobjektų saugojimas trimačiame geoinformacinès sistemos modelyje}

Požeminių inžinerinių komunikacijų trijų dimensijų geoinformacinès sistemos duomenu modelis suprojektuotas remiantis dabar esama stambiojo mastelio geoobjektų specifikacija [3], minètaisiais požeminių komunikacijų geoinformacinių duomenų kaupimo trimačiame geoinformacinès sistemos modelyje reikalavimais bei informacijos srautu analize. Duomenų modelis sukurtas taikant UML (unified modelling language) bei naudojant CASE (computer-aided software engineering) priemones, o geoinformaciniu duomenu bazè - naudojant ArcInfo ${ }^{\mathrm{TM}}$ programinę irangą. Geoduomenu bazè ikelta i centrinę duomenų bazę $\operatorname{ArcSDE}{ }^{\mathrm{TM}}$, kuri užtikrina prieinamumą daugeliui vartotojų, t. y. duomenų redagavimą ir peržiūrą iš daugiau nei vienos darbo vietos. ArcSDE $E^{\mathrm{TM}}$ leidžia saugoti 
geoinformacinių duomenų bazes komercinèse reliacinių duomenu baziu vadybos sistemose, tokiose kaip: $M S S Q L$ Server $^{\mathrm{TM}}$, Oracle ${ }^{\mathrm{TM}}$, - todèl duomenu modelis yra nepriklausomas. Sukurtas geoinformacinių duomenu modelis taip pat gali būti naudojamas pavieniame kompiuteryje (kaip Personal Geodatabase), todèl gali būti taikomas apsikeitimo duomenimis procedūrose. Tai ypač svarbu, nes geodezinius matavimus atliekančios imonès matavimų duomenis turi perduoti savivaldybès mero ar valdybos igaliotam savivaldybès padaliniui, o ši savo ruožtu atsakinga už kartografinès medžiagos saugojimą ir patikimą atnaujinimą. Pagal taisykles [6] topografinei nuotraukai sudaryti geodezininkas turi gauti duomenis iš savivaldybès mero ar valdybos igalioto savivaldybès padalinio, atlikti matavimus bei pateikti naujai sukurtos topografinès nuotraukos duomenis tam pačiam padaliniui. Taigi taikant ši modeli duomenys pirmiausia būtų ištraukiami iš centrinès duomenu bazès, keičiami atsijungus nuo centrinès duomenų bazès tame pačiame modelyje ir grąžinami atgal i centrinę bazę. Duomenų bazès modelio paskirtis - užtikrinti pakankamą geodezinių matavimu (topografinès ir geodezinès nuotraukos) informacijos saugojimą.

Trimačiame duomenų modelyje taikyti geometrinių primityvu tipai: PointZ, PolylineZ, PolygonZ, MultiPatch. Pirmieji tipai - standartiniai geometriniai primityvai, papildyti $z$ reikšmėmis, kurios nustatomos kiekviename linijų ir poligonų viršūnès taške (2 lentelè). MultiPatch (daugiasienis) tipas leidžia saugoti tūrinius objektus, tačiau šiems objektams ikelti turi būti atliekamos specialios procedūros naudojant $A r c G I S^{\mathrm{TM}}$ programinès irangos ArcObjects ${ }^{\mathrm{TM}}$ komponentus [7] arba specializuotas programines įrangas, turinčias apsikeitimo sąsajų su ArcGIS ${ }^{\mathrm{TM}}$ (pvz.: SketchUp ${ }^{\mathrm{TM}}$, AutoCad ${ }^{\mathrm{TM}}$ ).

Geoobjektų klasès sugrupuotos pagal 1 lenteleje pateiktas temas. I sukurtą duomenų modeli ikelti testiniai geoinformaciniai duomenys iš miesto geoinformacinès sistemos duomenų bazès.

İkèlus 2,5D erdvès duomenis tapo aišku, jog daugeliu atveju trūksta trečiosios $-z$ komponentès duomenu. Šiais duomenimis gali būti papildoma atliekant papildomus matavimus. Tais atvejais, kai duomenų netrūksta, galima taikyti altitudžių suteikimo inžinerinèms komunikacijoms algoritmą, skirtą duomenims konvertuoti i trimatę erdvę (2 pav.). Tūriniams objektams įvesti panaudotas tarpinis poligoninis PolygonZ geometriniu primityvu sluoksnis, vèliau duomenys konvertuoti į MultiPatch duomenų tipą.

\section{Geodeziniai ir fotogrametriniai matavimai požeminių komunikacijų geoduomenims kaupti}

Statomų požeminių tinklų ir komunikacijų geodezinių nuotrauku atlikimo tvarkoje [1] nurodoma, kad požeminių komunikacijų vertikalioji padètis (altitudès) nustatoma techninès niveliacijos būdu. Praktikoje požeminių komunikacijų geodezinių nuotraukų sudarymo darbams dažniausiai naudojami elektroniniai tacheometrai. Jais galima iškart matuoti ne tik horizontaliają komunikacijų padėti, bet ir vertikaliają. Tada matuojamos komunikacijos viršūnès padètis gauna ir altitudę, o remiantis matavimų rezultatais galima sukonstruoti reikalingus objektus bei perkelti $\mathfrak{i}$ atitinkamus sluoksnius. Sprendžiant objektų kodavimo standartizavimo problemą [8] būtina numatyti ir požeminių trimačių objektų kodavimo mechanizmą, o antžeminių trimačių objektų - kodavimą ir matavimų reikalavimus.

Atliekant stereofotogrametrinius matavimus gali būti atlikta požeminių komunikacijų elementų, kaip antai šulinių dangčių bei lietaus grotelių, kontrolè bei tikslinimas tais atvejais, kai esamos duomenų bazès yra

2 lentelè. Požeminių komunikacijų objektų transformavimo atvejai geometrinių primityvų požiūriu

Table 2. Transformation cases for geometrical primitives of underground utilities

\begin{tabular}{|l|l|l|}
\hline $\begin{array}{c}\text { Geometrinis } \\
\text { elementas 2D } \\
\text { erdvėje }\end{array}$ & \multicolumn{1}{|c|}{$\begin{array}{c}\text { Geometrinis elementas 3D } \\
\text { erdvėje }\end{array}$} & Objektai \\
\hline Taškas $(x, y)$ & taškas $(x, y, z)$ & $\begin{array}{l}\text { objektai, kuriuos galima laikyti neturinčiais aukščio, pvz.: } \\
\text { šlinių dangčiai, sklendès }\end{array}$ \\
\hline & $\begin{array}{l}\text { statmena linija (dvi } z \text { reikšmės } \\
\text { vienai } x, y \text { koordinačiu porai: } \\
\left.x_{1}, y_{1}, z_{1} \ldots x_{1}, y_{1}, z_{2}\right)\end{array}$ & $\begin{array}{l}\text { objektai, kuriuos galima laikyti turinčiais aukšti, pvz.: } \\
\text { stulpas, giluminis ižeminimo gręžinys }\end{array}$ \\
\hline Linija $\left(x_{1}, y_{1} \ldots x_{n}, y_{n}\right)$ & \multicolumn{1}{|c|}{} \\
\hline $\begin{array}{l}\text { Poligonas }\left(x_{1}, y_{1} \ldots x_{n},\right. \\
\left.y_{n}, x_{1}, y_{1}\right)\end{array}$ & \begin{tabular}{l} 
linija $\left(x_{1}, y_{1}, z_{1} \ldots x_{n}, y_{n}, z_{n}\right)$ \\
\hline
\end{tabular} & $\begin{array}{l}\text { objektai, turintys ilgio ir aukščio parametrą, kabeliai, } \\
\text { vandentiekio, dujų tiekimo vamzdžiai }\end{array}$ \\
\hline & $\begin{array}{l}\text { poligonas }\left(x_{1}, y_{1}, z_{1}, \ldots x_{n}, y_{n}, z_{n}, y_{1}, z_{1}\right) \\
\left.z_{n h}, x_{1}, y_{1}, z_{1}, z_{1 h}\right)\end{array}$ & $\begin{array}{l}\text { objektai, kuriuos galima laikyti plokščiais, ir turintys uždarą } \\
\text { kontūra, arba tūriniu objektų tarpinis geometrinis primityvas }\end{array}$ \\
\hline
\end{tabular}


sukurtos vektorizuojant senąsias 1:500 mastelio planšetes. Stereodigitalizavimo metodika ittraukiant inžinerinių tinklų šulinių dangčius bei groteles pateikta atlikus VGTU Geodezijos instituto Fotogrametrijos laboratorijos užsakomaji darbą [9].

\section{Matavimų rezultatų transformavimas i trimati geoinformacinès sistemos modeli}

Inžineriniu komunikacijų geoduomenims transformuoti $\mathfrak{i}$ trimatę erdvę sukurtas modulis Visual Basic ${ }^{\mathrm{TM}}$ programavimo kalba taikant ArcObjects ${ }^{\mathrm{TM}}$ komponentus. Algoritmo esmè (2 pav.) - pradinių inžinerinių komunikacijų linijinių objektų viršūnių $z$ reikšmès, nustatytos naudojant inžinerinių komunikacijų klojimo altitudžių reikšmes. Pirmajame - parametrų nuskaitymo bloke atliekamas duomenų sluoksnių identifikavimas nuskaitomas inžinerinių komunikacijų linijinis ir klojimo altitudžių taškinis duomenų sluoksniai, jei duomenys apriboti $S Q L$ užklausos, atliekama duomenų atranka. Antrajame - altitudžiu suteikimo bloke imama kiekviena linija ir kiekviena linijos viršūne ir jai ieškoma artimiausios altitudès, kuri būtų ne toliau kaip per $0,1 \mathrm{~m}$. Šis dydis galètú būti mažesnis, nes altitudès reikšmè turètų būti ,ant linijos“, t. y. taškas turètų būti susietas su linija (snap režimu), o atstumas - lygus 0, tačiau skirtingos programos siejimą traktuoja skirtingai, siejimas gali būti atliekamas topologiškai, t. y. taikant jungimo lenteles, bet ne geometriškai, t. y. padètys gali nesutapti. Sąlyga imta šiam dydžiui nustatyti - mažiausiasis atstumas tarp viršūnių - ne mažesnis nei $0,1 \mathrm{~m}$. Altitudžių paieškos algoritmas (3 pav.) atsišakoja nuo pagrindinio algoritmo taške „Ieškoti artimiausios altitudès, esančios ne toliau kaip per 0,1 m nuo viršūnès“", atlieka paieškos uždavini ir grịžta atgal i pagrindini algoritmą (2 pav.).

Atlikus altitudžių nustatymo procedūrą, tapo aišku, jog esant nepakankamai pradinių duomenų tik maža dalis inžinerinių linijų gavo $z$ reikšmę. Iš visų klojimo altitudžių tik dalis buvo panaudota viršūnių altitudėms nustatyti. Vilniaus teritorijos dalies - ribojamos Vilniaus, Kalvarijų, Šeimyniškių, Olandų, Krivių, Bernardinų, Šventaragio gatvių ir Gedimino prospekto, požeminių komunikacijų linijų altitudžių nustatymo testo rezultatai pateikti 3 lenteleje.

Lenteleje pateikti požeminių komunikacijų klojimo altitudžių suteikimo linijų viršūnèms rezultatai, gauti pagal šias formules:

$$
\begin{aligned}
& i_{s}=\frac{k_{H s}}{k_{H p}} \times 100, \\
& i_{p}=\frac{k_{H s}}{k_{v}} \times 100,
\end{aligned}
$$

čia $i_{s}$ - nustatytų altitudžių dalis iš viso pradinių altitudžių skaičiaus, $i_{p}$ - suteiktų altitudžių dalis iš visų viršūnių skaičiaus, $k_{H s}-$ suteiktų altitudžių skaičius, $k_{H p}$ - pradinių altitudžių skaičius, $k_{v}$ - viršūnių skaičius.

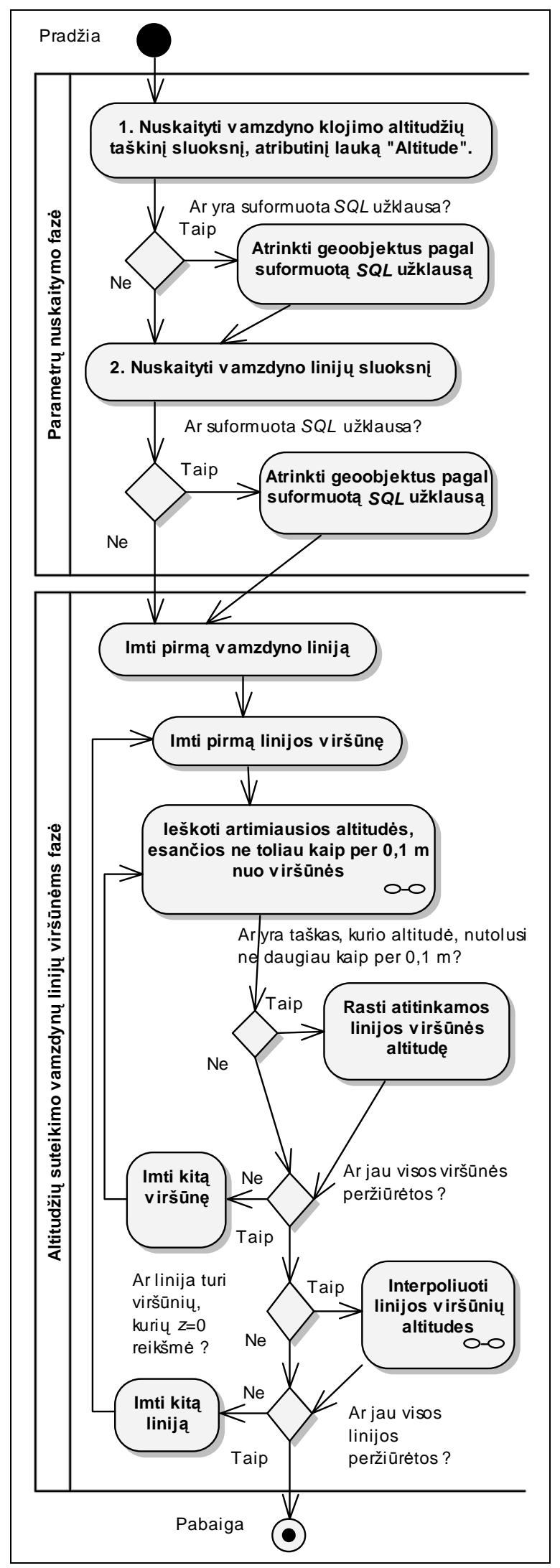

2 pav. Požeminių komunikacijų linijų altitudžių nustatymo algoritmo diagrama

Fig 2. Algorithm diagram of altitude transfer to underground utilities lines 
3 lentelè. Komunikacijų linijų altitudžių nustatymo rezultatai Table 3. Results of altitude transfer to utility lines

\begin{tabular}{|c|c|c|c|c|}
\hline $\begin{array}{c}\text { Komunikacijos } \\
\text { tipas }\end{array}$ & $\begin{array}{c}\text { Objektų } \\
\text { kiekis, } \\
k_{\text {obj }}\end{array}$ & $\begin{array}{c}\text { Viršūnių } \\
\text { skaičius, } \\
k_{v}\end{array}$ & $\begin{array}{c}\text { Nustatytu } \\
\text { altitudžiu } \\
\text { skaičius } \\
\text { (pradinių } \\
\text { altitudžiu } \\
\text { skaičius) } \\
k_{H s} \\
\left(k_{H p}\right)\end{array}$ & $\begin{array}{c}\text { Nustatytu } \\
\text { altitudžiu } \\
\text { dalis: iš } \\
\text { pradinių } \\
\text { altitudžiu } \\
\text { skaičiaus, } \\
\text { (iš visu } \\
\text { viršūnių } \\
\text { skaičiaus) } \\
i_{s} \\
\left(i_{p}\right)\end{array}$ \\
\hline $\begin{array}{l}\text { Elektros } \\
\text { tinklai }\end{array}$ & 4771 & 41933 & $\begin{array}{l}0 \\
(0)\end{array}$ & $\begin{array}{l}- \\
(-)\end{array}$ \\
\hline $\begin{array}{l}\text { Vandentiekio } \\
\text { vamzdynai }\end{array}$ & 1437 & 6848 & $\begin{array}{l}91 \\
(116)\end{array}$ & $\begin{array}{l}78,4 \% \\
(1,3 \%)\end{array}$ \\
\hline $\begin{array}{l}\text { Dujotiekio } \\
\text { vamzdynai }\end{array}$ & 702 & 2962 & $\begin{array}{l}118 \\
(100)\end{array}$ & $\begin{array}{l}118 \% \\
(4,0 \%)\end{array}$ \\
\hline $\begin{array}{l}\text { Naftotiekio } \\
\text { vamzdynai }\end{array}$ & 24 & 145 & $\begin{array}{l}0 \\
(0)\end{array}$ & $\begin{array}{l}- \\
(-)\end{array}$ \\
\hline $\begin{array}{l}\text { Śilumtiekio } \\
\text { komunikacijos }\end{array}$ & 1091 & 6041 & $\begin{array}{l}66 \\
(196)\end{array}$ & $\begin{array}{l}33,7 \% \\
(1,1 \%)\end{array}$ \\
\hline $\begin{array}{l}\text { Nuoteku } \\
\text { komunikacijos }\end{array}$ & 2782 & 9250 & $\begin{array}{l}9 \\
(23)\end{array}$ & $\begin{array}{l}39,1 \% \\
(0,1 \%)\end{array}$ \\
\hline $\begin{array}{l}\text { Ryšiu } \\
\text { komunikacijos }\end{array}$ & 147 & 1204 & $\begin{array}{l}0 \\
0\end{array}$ & - \\
\hline
\end{tabular}

Iš lentelëje pateiktų rezultatų matyti, kad elektros ir ryšių komunikacijų liniju pradiniuose duomenyse klojimo altitudžių nebuvo apskritai, todèl jos ir nebuvo nustatytos, o vamzdinių komunikacijų klojimo altitudžių nagrinejjamoje teritorijoje buvo mažai, palyginti su vamzdinių komunikacijų linijų viršūnių skaičiumi $(0,1 \%-4 \%)$, daugiausia buvo nustatyta vandentiekio ir dujotiekio vamzdynų klojimo altitudžių - atitinkamai $78,4 \%$ ir $118 \%$. Dujotiekio vamzdyno $i_{p}$ rodiklis viršija $100 \%$, vadinasi, tos pačios altitudès buvo nustatytos daugiau nei vienos viršūnès. Galima daryti prielaidą, kad atstumas tarp kelių viršūnių buvo mažesnis nei $0,1 \mathrm{~m}$, nes toks atstumas nurodytas kaip minimalus tarp viršūnių pradiniuose duomenyse.

Kai klojimo altitudžiu mažai, kai kuriais atvejais interpoliuojant šias altitudes galima gauti trūkstamas komunikacijų viršūnių altitudes.

Interpoliavimui atlikti pagrindinis algoritmas papildytas taikant šias viršūnių altitudžių interpoliavimo formules:

$$
\begin{aligned}
& H_{a}=h_{1}+D h \times a A /(a A+A b), \\
& H_{a k o n t r}=h_{2}-D h \times A b /(a A+A b),
\end{aligned}
$$

čia $D h$ - skirtumas tarp gretimų altitudžių $h_{2}-h_{1}, a A-$ atstumas iki interpoliuojamo taško nuo $h_{1}$ altitudès, $A b-$ atstumas iki interpoliuojamo taško nuo $h_{2}$ altitudès, $a A+A b$ - atstumas tarp gretimų altitudžių $h_{1}, h_{2}$. Interpoliavimo algoritmas atsišakoja nuo pagrindinio algoritmo taške „Interpoliuoti linijos viršūnių altitudes“, atlieka interpoliavimo algoritme numatytas užduotis ir grị̌zta atgal i pagrindinị algoritmą (2 pav.).
Interpoliuoti neịmanoma šiais atvejais: 1) kai linija turi tik vieną viršūnę su altitude, 2) kai linija turi dvi viršūnes su altitudèmis, kurios yra viena šalia kitos. Interpoliavimą galima atlikti tik tų viršūnių, kurios yra tarp viršūnių su žinomomis altitudèmis.

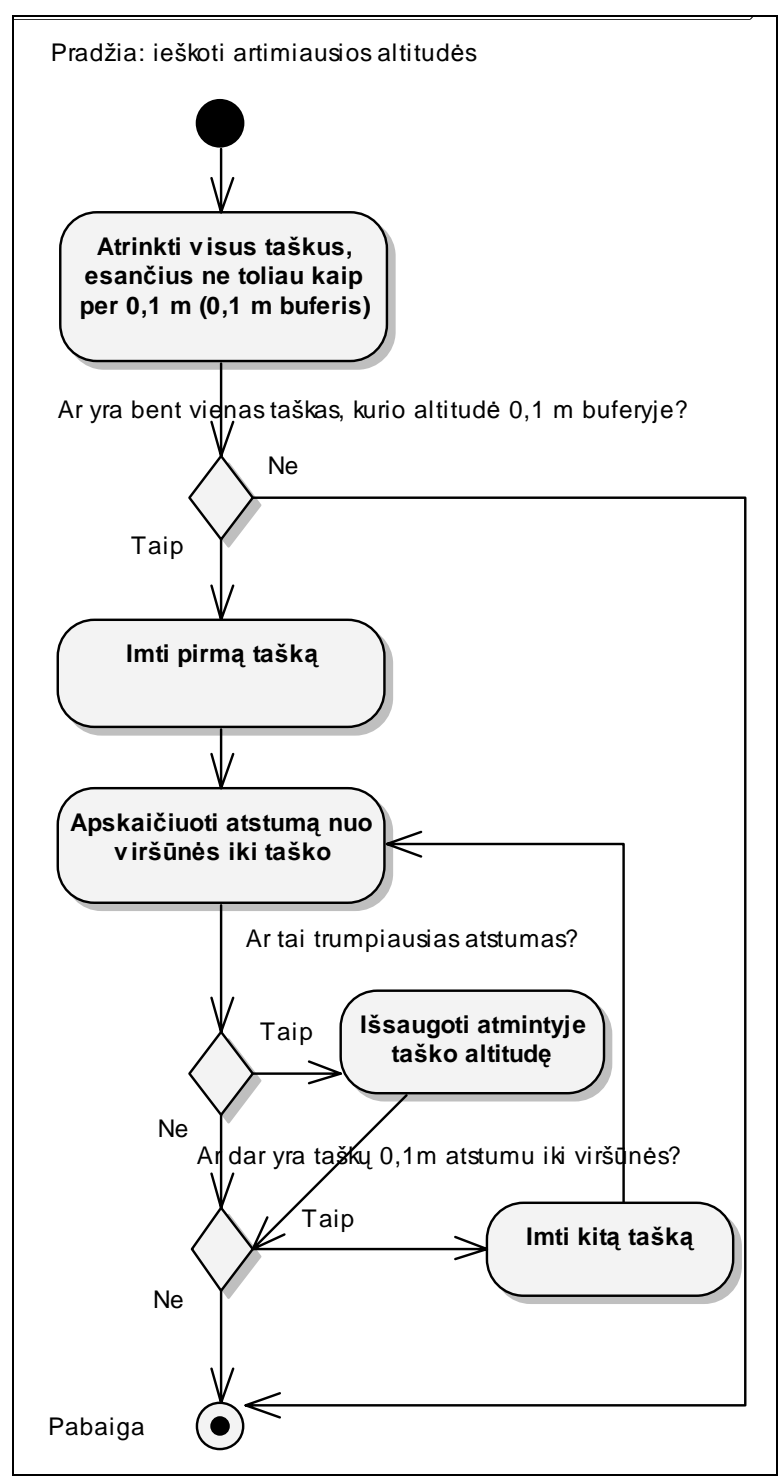

3 pav. Artimiausios altitudès radimo algoritmo diagrama Fig 3. Algorithm diagram of the closest altitude determination

Interpoliavimo rezultatai pateikti 4 lentelèje. Jie apskaičiuoti pagal šią formulę:

$$
i_{\text {pint }}=\frac{k_{H s}+k_{v \text { int }}}{k_{v}} \times 100
$$

čia $i_{\text {pint }}-$ nustatytų ir interpoliuotų altitudžių dalis iš visų viršūnių skaičiaus, $k_{H s}-$ nustatytų altitudžių skaičius, $k_{\text {vint }}$ - interpoliuotų viršūnių skaičius, $k_{v}$ - viršūnių skaičius.

Interpoliavimo rezultatai rodo, kad liniju viršūnių, kurių altitudès nustatytos, padaugejjo tik nežymiai $(0,1 \%-1,0 \%)$. Tai lèmé nedidelis tinkamų interpoliuoti objektų skaičius $(0,03 \%-2,1 \%)$. 
4 lentelė. Viršūnių altitudžiu interpoliavimo rezultatai Table 4. Results of altitude interpolation to utility's lines

\begin{tabular}{|l|l|l|l|}
\hline $\begin{array}{c}\text { Komunikacijos } \\
\text { tipas }\end{array}$ & $\begin{array}{c}\text { Interpoliuotų } \\
\text { objektų } \\
\text { kiekis, } k_{\text {objint }} \\
\text { (visų objektų } \\
\text { dalis) }\end{array}$ & $\begin{array}{c}\text { Interpoliuotu } \\
\text { viršūnių } \\
\text { skaičius, } \\
k_{\text {vint }}\end{array}$ & $\begin{array}{c}\text { Nustatytu ir } \\
\text { interpoliuotu } \\
\text { altitudžių } \\
\text { dalis iš visų } \\
\text { viršūnių } i_{\text {pint }} \\
\text { (pokytis, } \Delta)\end{array}$ \\
\hline $\begin{array}{l}\text { Vandentiekio } \\
\text { vamzdynai }\end{array}$ & $3(0,2 \%)$ & 34 & $\begin{array}{l}1,8 \% \\
(+0,5 \%)\end{array}$ \\
\hline $\begin{array}{l}\text { Dujotiekio } \\
\text { vamzdynai }\end{array}$ & $15(2,1 \%)$ & 29 & $\begin{array}{l}5,0 \% \\
(+1,0 \%)\end{array}$ \\
\hline $\begin{array}{l}\text { Śilumtiekio } \\
\text { komunikacijos }\end{array}$ & $2(0,2 \%)$ & 21 & $\begin{array}{l}1,4 \% \\
(+0,3 \%)\end{array}$ \\
\hline $\begin{array}{l}\text { Nuotekų } \\
\text { komunikacijos }\end{array}$ & $1(0,03 \%)$ & 5 & $\begin{array}{l}0,2 \% \\
(+0,1 \%)\end{array}$ \\
\hline
\end{tabular}

\section{Išvados}

1. Apibrěžti papildomi požeminių komunikaciju geoinformaciniu duomenu kaupimo trimačiame geoinformacinès sistemos modelyje reikalavimai.

2. Laikantis papildomu reikalavimu, taikant $U M L$ bei CASE priemones sukurtas požeminių komunikacijų 3D geoinformacinių duomenų modelis.

3. Sukurtas inžinerinių komunikacijų linijų viršūniu siejimo su inžineriniu komunikaciju klojimo altitudèmis algoritmas, eksperimentui atlikti sukurtas programinis modulis, veikiantis $\operatorname{ArcGIS} S^{\mathrm{TM}}$ aplinkoje. Eksperimento metu pradiniai geoinformaciniai duomenys transformuoti i 3D erdvę, taikant klojimo altitudžiu siejimo su požeminių komunikacijų linijų viršūnèmis algortimą. Elektros ir ryšių komunikacijų linijų pradiniuose duomenyse klojimo altitudžiu reikšmių nebuvo, todèl jos nebuvo nustatytos, o vamzdiniu komunikaciju klojimo altitudžių nagrinèjamoje teritorijoje buvo mažai, palyginti su vamzdinių komunikacijų liniju viršūniu skaičiumi $(0,1 \%-4 \%)$; daugiausia buvo nustatyta vandentiekio ir dujotiekio vamzdynų klojimo altitudžių - atitinkamai $78,4 \%$ ir $118 \%$. Dujotiekio vamzdyno $i_{p}$ rodiklis (nustatytų altitudžių dalis iš visų viršūnių skaičiaus) viršija $100 \%$, vadinasi, tos pačios altitudès buvo nustatytos daugiau nei vienos viršūnès.

4. Požeminių komunikacijų linijų viršūniu altitudžiu nustatymo rezultatams pagerinti buvo sukurtas eksperimentinis linijų viršūnių altitudžių interpoliavimo algoritmas bei interpoliavimo programinis modulis, veikiantis $A r c G I S^{\mathrm{TM}}$ aplinkoje.

\section{Literatūra}

1. Underground network and implementation procedure of geodesy communication survey, Regulation GKTR 2.01.01:1999, National Service of Geodesy and Cartography. Vilnius, 1999, p. 1-14 (in Lithuanian).

2. Geodetic engineering investigations, Regulation GKTR 2.08.01:2000, National Service of Geodesy and Cartography. Vilnius, 2000, p. 1-32 (in Lithuanian).

3. Stankevičius, Ž. Investigation of city geographic information system optimality. PhD dissertation. Vilnius, 2000, p. 1-164 (in Lithuanian).

4. Stoter, E.; Ploeger, H. D. Property in $3 \mathrm{D}$ - registration of multiple use of space: current practice in Holland and the need for a 3D cadastre. Computers, Environment and Urban Systems, Vol XXVII, 2003, p. 553-570.

5. Čypas, K. Construction peculiarities of topological 3D model for underground infrastructure. In: Proceedings of $6^{\text {th }}$ International Conference on Environmental Engineering, May 26-27, Vol 2, Vilnius, 2005, p. 847851.

6. Stankevičius, Ž. Fixing of changes in a city cartography of large scale. Geodesy and Cartography (Geodezija ir kartografija), Vol XXV, No 3, Vilnius: Technika, 1999, p. 91-96 (in Lithuanian).

7. Ford, A. The visualisation of integrated 3D petroleum datasets in ArcGIS. In: Proceedings of $24^{\text {th }}$ ESRI user conference, 2004, San Diego, p.1-11.

8. Stankevičius, Ž.; Paršeliūnas, E. Standartisation of large scale geodata sets. In: Proceedings of $6^{\text {th }}$ International Conference on Environmental Engineering, May 26-27, Vol 2, Vilnius, 2005, p. 1008-1013.

9. Žalnierukas, A.; Sužiedelytė-Visockienè, J. Research of stereophotodigital method by including in CDB the elements of underground engineering nets. Geodesy and Cartography (Geodezija ir kartografija), Vol XXVII, No 1. Vilnius: Technika, 2001, p. 20-23 (in Lithuanian).

Kęstutis ČYPAS. Doctoral student. Vilnius Gediminas Technical University, Dept of Geodesy and Cadastre, Saulètekio al. 11, LT-10223 Vilnius-40, Lithuania (Ph +37052744703), e-mail: kestutis.cypas@ap.vtu.lt.

A graduate of Vilnius Gediminas Technical University (VGTU) (MSc, 2001). Post graduate studies at Gjoevik University College in 1998. Author of 4 publications.

Research interests: geoinformation systems, 3D modelling. 